\title{
Risks, Challenges and Countermeasures of the Co-construction of "the Belt and Road" High-quality Development
}

\author{
Zi Wang ${ }^{1, *}$ Hongtao Shan ${ }^{1}$ Yi Zhang ${ }^{1}$ Mengqi Zhang ${ }^{1}$ Hui Liu ${ }^{1}$ Junfei Bi \\ ${ }^{1}$ Political Theory Teaching and Research Office, College of Information and Communication, National \\ University of Defense Technology, Xi'an, Shaanxi 710106, China \\ *Corresponding author. Email: prince0828@163.com
}

\begin{abstract}
Since the introduction of the Belt and Road Initiative, it has moved from planning to practice, its volume is getting bigger and bigger, its radiation is getting wider and wider, its connotation is getting richer and richer, and its role is getting more and more prominent. China is bringing the countries along the route to the center of the world economic stage. As an old saying goes, one should try to do still better after having achieved a fair degree of success; against the background of accelerating changes in the world pattern, the COVID-19 pandemic raging around the world, as well as the flagging world economy, the risks and challenges faced by the co-construction of "the Belt and Road" high-quality development are unprecedented. Under the premise of clarifying the significance of the construction of the Belt and Road, this article analyzes the risks and challenges faced by the construction of "the Belt and Road", and proposes countermeasures to jointly build the high-quality development of "the Belt and Road".
\end{abstract}

Keywords: "The Belt and Road", Risks and challenges, High-quality development.

\section{INTRODUCTION}

Since 2013, the construction of "the Belt and Road" [1] continues to set down roots and be put into practice, playing a positive role in promoting the economic development of China and the world. After 7 years of development and construction, the volume of "the Belt and Road" becomes bigger and bigger, its radiation is getting wider and wider [2], its connotation is getting richer and richer, and its role is getting more and more prominent, advantageously promoting the building of a community of common future for mankind.

\section{THE SIGNIFICANCE OF "THE BELT AND ROAD" CONSTRUCTION}

China has entered a new journey of socialist modernization, and the world pattern continues to evolve at an accelerated pace. The construction of "the Belt and Road" has a more profound significance for the great rejuvenation of the
Chinese nation and the common development of the world.

\subsection{A "Multiplier" That Realizes the Great Rejuvenation of the Chinese Nation}

Realizing the "two centenary" goals and the great rejuvenation of the Chinese nation is the greatest dream of the Chinese people since modern times, and it is also the goal, mission and pursuit of contemporary China's development and progress. Standing at the strategic height of the great rejuvenation of the Chinese nation, the construction of "the Belt and Road" is a "multiplier" for realizing the great rejuvenation of the nation.

Firstly, it's conducive to consolidating the material foundation for national rejuvenation. The foundation for realizing the great rejuvenation of the Chinese nation is the economy. Only when the economy develops sustainably and healthily can there be a reliable guarantee for the great rejuvenation of the Chinese nation. The construction of "the Belt and Road" is beneficial to 
promote the economic development of China's economy. Especially inland areas such as Xinjiang, Gansu, Shaanxi, etc., which are relatively backward in the traditional sense, are both the builders of "the Belt and Road" and the beneficiaries of "the Belt and Road". The construction of "the Belt and Road" has made them the forefront of China's opening up to the outside world, which greatly matches the development strategy of China's central and western regions. And as "the Belt and Road" construction enters the stage of high-quality development, the material foundation for the great rejuvenation of the Chinese nation will become more abundant and sufficient.

Secondly, it's conducive to building a new security pattern for national rejuvenation. China is one of the countries with the most neighboring countries in the world. In international competition, the more neighbors, the more disadvantaged. From the perspective of land, the Eurasian region is the center of the international political arena. In recent years, the activities of the "three forces" in this region have become increasingly rampant. From the perspective of sea, along the "Maritime Silk Road" in the 21 st century, there are still some disputes over territorial waters, islands and reefs, and maritime rights and interests in related countries, and maritime criminal activities such as piracy also exist to varying degrees. As the world's economic and strategic center of gravity continues to shift to the Asia-Pacific region, the Asia-Pacific region remains the focus of the game among the world's major powers. The security of the Asia-Pacific region has uncertainties and instabilities that directly affect China's overall security strategy. On the one hand, it's needed to actively respond to these security threats, and on the other hand, it's needed to actively shape a favorable security pattern. The construction of "the Belt and Road" has prompted China to establish strategic partnerships with countries and regions along the route, shortened the distance between each other, played the security value of "the Belt and Road", and further built a favorable security strategic pattern.

Thirdly, it's conducive to creating a peaceful international environment for national rejuvenation. The entry of socialism with Chinese characteristics into a new era means that the Chinese nation has ushered in a great leap from standing up, getting rich to becoming strong, and it also means that scientific socialism is full of vitality, and China's status and influence in the world are rising rapidly. But for thousands of years, from ancient Rome to
Netherlands, from the United Kingdom to the United States, after the rise of great powers, they have sought hegemony and brought endless wars and conflicts to the world, which seems to be an unchanging historical logic. Although China has repeatedly stated and demonstrated through practical actions that China pursues peace and doesn't seek hegemony, due to differences in political systems, ideologies, and development paths, etc., some countries in the world are full of doubts about China's rapid rise, which has aroused concerns, especially the strategic containment of China by major powers in the world. China urgently needs to establish a good international environment to eliminate or reduce doubts and create a peaceful development environment for national rejuvenation. The construction of "the Belt and Road" will become an important bridge for China to shape a good international image that pursues peace and inclusiveness.

\subsection{A "Cardiotonic" to Promote World Recovery and Development}

Since the outbreak of the international financial crisis in 2008, the world's economic growth has been weak, coupled with the COVID-19 pandemic raging around the world, the development of the present world is very sluggish. "the Belt and Road" construction not only meets the actual needs of world economic development, but also provides new opportunities for countries around the world to complement each other's advantages and develop together [3].

The first is to promote the prosperity and stability of countries and regions along the route. Most of the countries along "the Belt and Road" construction are developing countries. Most of these developing countries are in the initial or accelerated stage of industrialization and urbanization, and are facing urgent pressure from national development and the rapid improvement of people's living standards. The construction of "the Belt and Road" has been based on complementing each other's advantages in 7 years, connecting China's development with the development of countries along the route, effectively helping developing countries along the route to overcome the shortcomings of outdated infrastructure, shortage of construction funds, and lack of technical experience, and enabling the development of some countries along the route to show an unprecedented momentum of development [4]. For example, the opening of the Mombasa-Nairobi 
Standard Gauge Railway has provided 30,000 employment positions for Kenya and increased the GDP of Kenya as a whole by one percentage point. From January to July 10, 2020, the Mombasa-Nairobi Standard Gauge Railway transported a total of 207,000 TEUs of goods, including more than 5,000 boxes of grain and 90 boxes of epidemic prevention supplies such as disinfectants. The Mombasa-Nairobi Standard Gauge Railway is not only a major economic artery, but also a major artery of life and health.

The second is to inject new impetus into the common development of the world. The current COVID-19 pandemic is sweeping the world, the world economy has been hit hard, and its development is very sluggish. Under such circumstances, the construction of "the Belt and Road" is still playing the role of a cardiotonic, providing an important platform and channel and injecting new impetus for promoting the recovery of the global economy and revitalizing the economic cycle. The Eurasian Economic Union, the "Master Plan on ASEAN Connectivity 2025", the European Investment Plan, the Development Road initiative of Mongolia, the "Turning a Land-locked Country Into a Land-union Country" of Laos, the Northern Powerhouse Initiative of the UK, the "Vision 2030" of Saudi Arabia, and the "Thailand 4.0" of Thailand and so on, have already achieved policy or planning docking with "the Belt and Road". For example, as a landmark achievement of the "the Belt and Road" construction of the China Railway Express to Europe, as of November 5, 2020, there were 10,180 China railway expresses to Europe traveling between China and 21 European countries and 92 European cities. Since the outbreak of the COVID-19 pandemic, the China Railway Express to Europe has bucked the trend and developed in the context of the suspension of flying of international passenger air routes, road blockages, and stagnant water transport. China has transported about 7.51 million pieces and 62,000 tons of anti-epidemic materials to Europe. The China Railway Express to Europe has become a veritable "lifeline" of international logistics and a main road of the "Silk Road of Health Cooperation". It has strongly promoted global epidemic prevention and control, resumption of work and production, and economic recovery. "the Belt and Road" connects the world's big and small countries, connects developed and developing countries, connects China and the world, and becomes a bridge and tie for a community of common future for mankind.

\section{RISKS AND CHALLENGES FACED BY "THE BELT AND ROAD" CONSTRUCTION}

Great undertakings are always faced with risks and challenges. The risks and challenges faced by "the Belt and Road" construction come from many aspects. Especially under the situation that the COVID-19 pandemic hits the world, the world economy is in deep recession, turmoil and risk points have increased significantly in various regions, and unilateralism, protectionism, and hegemonism have increased [5]. This not only poses a serious threat to world peace and development, but also brings interference and destruction to the construction of "the Belt and Road".

\subsection{External Oppression Caused by the Strategic Game of World Powers}

With important strategic regional advantages and abundant natural resources along "the Belt and Road", it is the most potential economic cooperation belt in the world. Central and Western Asia is rich in natural resources. For example, Turkmenistan contains as much as one cubic meter of natural gas at every step; East Asian countries have a high degree of economic development and have a large amount of relatively mature technology reserves. For example, China leads the world in manufacturing technology; South Asia has obvious regional advantages and is the only route for non-Eurasian maritime trade. For example, in the capital of Sri Lanka, the Colombo Harbour is known as the "Eastern Crossroad"; Southeast Asian countries have abundant human resources and low labor costs. For example, in Vietnam, the average monthly salary of industrial workers is less than US\$200. It is precisely because of these outstanding advantages that major world powers such as the United States, Russia, and Japan have all implemented strategic measures in these regions to strengthen their influence along "the Belt and Road", and the game in the regions along "the Belt and Road" will inevitably become more intense.

\subsection{Contradictory Resistance Brought About by the Policy of "Sitting on the Fence" of Cooperative Countries}

In the construction of "the Belt and Road", many countries that have signed "the Belt and Road" cooperation agreement with China on the surface and have obtained the economic dividends 
brought by "the Belt and Road" are actually creating different varietas politically and militarily of the "China threat theory" such as the "Chinese overseas students espionage theory", "senators accepting China's sponsorship theory", "China 5G undermining security theory" and so on that are harmful to China. As a result, the construction of "the Belt and Road" is only economically connected, but there is a lack of trust between political and cultural exchanges. A great strategy falls to ordinary bilateral economic and trade exchanges, failing to achieve the original intention of "the Belt and Road" construction.

\subsection{Unstable Situation in Relevant Regions Brings Security Risks}

From a development perspective, "the Belt and Road" is an economic cooperation belt with great potential, but from a security perspective, it is a "arc of instability". Since 2020, the situation in Afghanistan has deteriorated sharply, the flames of war in the Naka region has reignited, and the assassination of the Iranian nuclear scientist has affected regional tense situation, leading to a rapid increase in security risks in key nodes of "the Belt and Road" construction in South Asia, Central Asia, and the Middle East. This is all related to the security situation of "the Belt and Road".

\section{COUNTERMEASURES FOR THE JOINT CONSTRUCTION OF "THE BELT AND ROAD" HIGH-QUALITY DEVELOPMENT}

"The Belt and Road" construction has both development opportunities and risks and challenges. These opportunities and risks will also increase as "the Belt and Road" construction moves towards high-quality development, which will also put forward higher requirements for safety guarantee in "the Belt and Road" construction.

\subsection{Actively Creating a Surrounding Environment that Strengthens the Foundation and Secures Neighboring Countries}

The frontier area is the foundation of development and prosperity. If the frontier area is restless, the world will be intranquil. It is China's steadfast national policy to do a good job of securing, strengthening, and using the frontier area. Regions along "the Belt and Road" all pass through or connect China's land and sea boundaries, which are related to the country's core development interests. The inability to guarantee the security of China's frontiers will directly bring huge challenges to the construction of "the Belt and Road". This requires China to resolutely defend the "frontier interests" of territorial sovereignty, but also to safeguard the "interest frontiers" of "the Belt and Road", and maintain a stable development environment and development interests.

\subsection{Actively Creating an International Environment for the Expansion of Interests}

With the vigorous advancement of "the Belt and Road" construction, Chinese personnel and assets are widely distributed all over the world, forming a huge overseas interest pattern. China's overseas interests continue to expand. The greater the overseas interests and the greater the need for security, the more difficult the mission and task of safeguarding the security of overseas interests. In recent years, China's overseas operations such as providing escort for Gulf of Aden, the evacuation of overseas Chinese from Libya, and the evacuation of overseas Chinese from Yemen have accumulated some valuable experience for China. At the same time, China should establish an overall security awareness, and on the premise of ensuring national sovereignty and territorial security, pay more attention to the security of overseas assets and personnel as well as to the security threats posed by non-traditional security. China needs to ensure that security guarantees extend wherever its overseas interests extend.

\subsection{Actively Creating a Public Opinion Environment that Is Friendly, Sincere, Mutually Beneficial and Inclusive}

From the perspective of global development trends, building a community of common future for mankind is an irresistible trend and the popular sentiment. At present, the international community has increasingly become a community of common future and shared security. The security and development of any country are closely related to world peace and prosperity. It is impossible for any country to develop independently from other countries. From the perspective of China's development situation, with China's development, especially after the outbreak of the COVID-19 pandemic, China's Chinese solutions and Chinese power for the recovery of the world economy and 
the prevention and control of the pandemic have made China increasingly influential in the world [6]. And a country with strong international influence should look like a great power. China has established the international image of China as a peaceful country and the Chinese people yearning for peace through public security goods such as "Peace Ark" hospital ship and Chinese peacekeeping in the hearts of the people of the countries and regions along "the Belt and Road", establishing a good international reputation.

\section{CONCLUSION}

After more than 7 years of development, "the Belt and Road" construction has changed from a strategic vision to a realistic path and platform for China and the world to develop together. It is a Chinese solution to world development problems and embodies Chinese wisdom. As "the Belt and Road" enters the stage of high-quality development, while seeing its broad prospects, people should also realize that the high-quality development of "the Belt and Road" will not be like a plain sailing. It is also faced with risks and challenges, which will become a great test on the road of high-quality development of "the Belt and Road".

\section{AUTHORS' CONTRIBUTIONS}

Zi Wang, Hongtao Shan, Yi Zhang, Mengqi Zhang wrote the manuscript, and Hui Liu, Junfei Bi contributed to revising and editing.

\section{REFERENCES}

[1] The Central Committee of the Communist Party of China on the Formulation of the Fourteenth Five-Year Plan for National Economic and Social Development and the Construction of Long-term Goals for 2035. People's Daily [N], 2020-10-30. (in Chinese)

[2] Zhang Dongyuan, Wang Jue. Identify the key points for high-quality joint construction of the "Belt and Road" [J]. People's Forum. 2019(22). (in Chinese)

[3] Xi Jinping. The First Volume of Xi Jinping on State Governance $[\mathrm{M}]$. Beijing: Foreign Languages Press, 2018.1. (in Chinese)

[4] Zheng Xueping, Lin Yueqin. The "Belt and Road" construction progress, challenges and countermeasures to promote high-quality development [J]. Northeast Asia Forum. 2020(06). (in Chinese)

[5] Wang Yajun. Building a Strong Security Barrier for "the Belt and Road" Construction in the Context of the Great Turbulent Situation [N]. Study Times, 2020-12-18. (in Chinese)

[6] $\mathrm{Hu}$ Biliang. Promoting the high-quality development of the "Belt and Road" joint construction - $\mathrm{Xi}$ Jinping's systematic discussion on the high-quality joint construction of the "Belt and Road" [J]. Learning and Exploration. 2020(10). (in Chinese) 